\title{
Effects of Particle Size Distribution on the Properties of Natural-Based Composite
}

\author{
Abutu Joseph, Lawal Sunday Albert, Ndaliman Mohammed Baba, Lafia-Araga Ruth Anayimi \\ and Abdulrahman Asipita Salawu
}

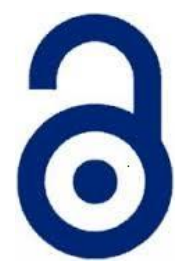

Received: 03 October 2019

Accepted: 09 November 2019

Published: 15 December 2019

Publisher: Deer Hill Publications

(C) 2019 The Author(s)

Creative Commons: CC BY 4.0

\begin{abstract}
In this study, locally sourced natural materials (coconut shells and seashells) were used separately to produce composites. The powders were sieved with sieve size of $10 \mu \mathrm{m}$ and characterized using a particle size analyser (DLS) in order to ascertain their particle size distribution. Also, the effects of particle size distribution on the performance of sourced coconut shells and seashells-based composite was investigated. About $52 \%$ of the characterized powder was afterward used along with other ingredients (35\% binder, $8 \%$ alumina and $5 \%$ graphite) to produced composites using moulding pressure (14 MPa), moulding temperature $\left(160^{\circ} \mathrm{C}\right)$, curing time $(12 \mathrm{~min})$ and heat treatment time $(1 \mathrm{hr})$. The performance of the composites was thereafter evaluated using standard testing procedures. The results of particle size analysis indicated that the seashell powder $(0.27)$ possesses lower distribution width (PDI) compared to the coconut shell powder (0.342) while the coconut shell $(542.3 \mathrm{~nm})$ showed lower Z-average diameter compared to the seashell powder $(1096 \mathrm{~nm})$ with some little traces of nanoparticles $(<10 \mu \mathrm{m})$. Also, the experimental results obtained from composite characterization indicated that the coconut shell-based samples exhibited better performance in terms of its mechanical and tribological properties compared to the seashell-based samples.
\end{abstract}

Keywords: Coconut shells, seashells, particle size analysis, composite, dynamic light scattering

\section{INTRODUCTION}

It was reported that particles of different sizes in a given powder have different flow and packing properties that tend to alter the volume of a powder (Chamoli et al., 2008). Subhash et al. (2017). Coconut shell powder (Fig. 1b) is obtained from agricultural wastes and used in the preparation of various attractive articles (antiques) and also applied in the production of activated charcoal as well as reinforcement material in the production of composites. In addition, powder of natural materials such as seashell (exoskeletons of mollusks) are mainly composed of calcium carbonate, intermediate layer (calcite) and the outer layer of horny substance known as conchiolin (Schaeffer, 2014). Salmah et al. (2013) reported that coconut shells are lignocellulosic filler which exhibits excellent properties compared to mineral fillers (kaolin, calcium carbonate, mica and talc). Some of the outstanding properties reported by the author include minimal health hazard, high-specific strength-to-weight ratio, low cost, biodegradability, environmental friendly and renewability. Also, Matthew (2012) reported that moisture desorption of coconut shells takes place between 25 and $150{ }^{\circ} \mathrm{C}$ and at $150{ }^{\circ} \mathrm{C}$, degradation of sclerenchyma cells, which are responsible for holding water in the shell occurs. Further heating of the shells between $190^{\circ} \mathrm{C}$ to $260^{\circ} \mathrm{C}$ may result to the degradation of hemicellulose present in the shell and at $240^{\circ} \mathrm{C}$ to $350^{\circ} \mathrm{C}$, degradation of cellulose take place. The final stage of thermal degradation involves the breakdown of lignin which occurs between $280{ }^{\circ} \mathrm{C}$ and $500{ }^{\circ} \mathrm{C}$ (Matthew, 2012). Therefore, in this study, powders were prepared from two locally sourced natural raw materials (coconut shell and seashell) and characterized using particle size analyser (zetasizer nano) with the aim of comparing the particle size distribution of the powder particles when sieved using the same sieve size and analysed by the similar equipment and testing conditions.

\footnotetext{
Abutu, J.', Lawal, S. A. ${ }^{1}$, Ndaliman, M. B. ${ }^{1} \bowtie$, Lafia-Araga, R. A. ${ }^{2}$, Abdulrahman A.S. ${ }^{3}$

'Department of Mechanical Engineering

2Department of Chemistry

3Department of Material \& Metallurgical Engineering

Federal University of Technology, Minna

P.M.B, 65 Minna, Niger State, Nigeria

E-mail: mbndaliman@futminna.edu.ng
}

Reference: Abutu, J., Lawal, S. A., Ndaliman, M. B., Lafia-Araga, R. A. and Abdulrahman A. S. (2019). Effects of Particle Size Distribution on the Properties of Natural-Based Composite. International Journal of Engineering Materials and Manufacture, 4(4), 170-177. 


\section{LITERATURE REVIEW}

Pei-Jia et al. (2018) suggested that, in order to select the appropriate dispersing and solvent agents, it is important to have sufficient knowledge of the basic chemical properties when preparing a well-dispersed powder suspension for DLS characterization. As a result, in the work of Tanmaya (2011), the elemental composition (proximate) and content distribution (ultimate) of coconut shell powder were investigated using CHNSO elemental analyser (Variael CUBE, Germany). The results of proximate and ultimate analysis of the coconut shell powder are shown in Table 1. Based on the findings presented in Table 1, the author concluded that, coconut shell has good amount volatile content to be used as a material for composite production. Also, Norazlina et al. (2015) revealed that seashell primarily consist of calcium carbonate $\left(\mathrm{CaCO}_{3}\right)$, been naturally above $80 \% \mathrm{CaCO}_{3}$ by weight with only about $2 \%$ protein content and no complex extraction process is needed to use it for composite production. Seashell exhibit significant combinations of low weight, toughness, stiffness and strength which are in some cases unrivalled by mineral fillers (Vignesh et al. 2015). Table 2 shows the chemical composition of a commercial calcium carbonate and calcium carbonate obtained from seashell as reported by Michele et al. (2012). The seashell powder used in the study was utilised as filler by the authors to produce a composite using polyester binder. The test results indicate that the commercial $\mathrm{CaCO}_{3}$ based composite possesses an impact and tensile strength of $918 \mathrm{MPa}$ and $3.2 \mathrm{kJm}^{-2}$ respectively while seashell-based composite exhibit an impact and tensile strength of $904 \mathrm{MPa}$ and $3.4 \mathrm{kJm}^{-2}$ correspondingly. The authors concluded that seashell can be used in place of commercial $\mathrm{CaCO}_{3}$ to produce composites since commercial $\mathrm{CaCO}_{3}$ and seashell (mussel or oyster shells) produces similar results regardless of their variation in distribution of particle size or particle sizes.

Nia et al. (2012) in their study, demonstrated six submicron particle sizing techniques which include dynamic light scattering (DLS), scanning mobility particle sizing, particle tracking analysis (PTA), tunable resistive pulse sensor (TRPS), transmission electron microscopy (TEM) and differential centrifugal sedimentation (DCS). One of the commonly used technique, Dynamic light scattering (DLS) measures the particle size of sieved powder by determining the average hydrodynamic diameter of a particle suspension through measurement of the changes produced by particles scattering light in a speckle pattern moving under Brownian motion (Will et al., 2013). Pei-Jia et al. (2018) also revealed that DLS is a relatively affordable and fast tool which can be used for determining the size distribution, polydispersity index (PDI) and mean size of a nanoparticle sample. A device known as zetasizer (The world's most widely used systems for nanoparticle) which incorporates two techniques in a distinct condensed unit, and has a range of accessories and options to optimise as well as simplify the size of different sample type can be used in this technique (DLS). Hermann (2009) also revealed that there is need to characterize sourced powdered particles. Some of the reasons highlighted by the author include to:

i. study the behaviour in a specific environment

ii. study the characteristics of different powdered material for specific applications

iii. achieve optimization during production of the composite.

iv. study the interaction of the sourced material with biological systems.

Therefore, in this study, the effects of particle size distribution on the performance of locally sourced coconut shells and seashells-based composite was investigated by characterizing the powders and developed composite using particle size analyser (Zetasizer nano) and standard testing methods respectively.

Table 1: Proximate and ultimate analysis of coconut shell powder Source: Tanmaya (2011)

\begin{tabular}{lclc}
\hline Content & Proximate analysis $(\% \mathrm{w} / \mathrm{w})$ & \multicolumn{2}{c}{ Elemental composition (\%) } \\
\hline Moisture content & 10.1 & Oxygen & 22.61 \\
Fixed carbon & 11.2 & Hydrogen & 4.89 \\
Ash content & 14.2 & Sulphur & 3.50 \\
Volatile matter & 64.6 & Nitrogen & 4.77 \\
& & Carbon & 64.23 \\
\hline
\end{tabular}

Table 2: Chemical composition of seashell and commercial $\mathrm{CaCO}_{3}$ Source: Michele et al. (2012).

\begin{tabular}{|c|c|c|}
\hline Oxides & $\mathrm{CaCO}_{3}$ from seashell (\%) & Commercial $\mathrm{CaCO}_{3}(\%)$ \\
\hline $\mathrm{CaO}$ & 95.7 & 99.1 \\
\hline $\mathrm{SO}_{3}$ & 0.7 & - \\
\hline $\mathrm{SiO}_{2}$ & 0.9 & - \\
\hline $\mathrm{K}_{2} \mathrm{O}$ & 0.5 & 0.4 \\
\hline $\mathrm{Fe}_{2} \mathrm{O}_{3}$ & 0.7 & - \\
\hline $\mathrm{Al}_{2} \mathrm{O}_{3}$ & 0.4 & - \\
\hline $\mathrm{MgO}$ & 0.6 & - \\
\hline $\mathrm{SrO}$ & 0.4 & - \\
\hline
\end{tabular}




\section{RESEARCH MATERIALS}

The seashell and coconut shell used in this study as shown in Figure 1 and Figure 2 were sourced locally. Seashells (the shells of sea snails) were collected from a local seafood vendor situated in Lagos bar beach, Lagos - Nigeria, while coconut shells were obtained from a coconut trader in a Sabon Tasha market in Kaduna - Nigeria. Sieving of the ground seashell and coconut shell was done using sieve of $10 \mu \mathrm{m}$ mesh size.

\subsection{Particle size Analysis}

Particle size analysis of the sieved powder was conducted using a particle size analyser [Zetasizer (Nano series), Model: ZEN1600, S/N: MAL1084260, Malvern, UK] connected to a computer system (Figure 3) situated at the Centre for Genetic Engineering and Bio-Technology (STEP B) in Federal University of Technology, Minna, Nigeria.

\subsection{Production of Composites}

Materials used in the production of the seashell and coconut-shell reinforced composites are shown in Table 3. Also, production of composites was carried at the Federal College of Chemical and Leather Technology (FCCLT), Samaru, Zaria (Polymer workshop) using a compression moulding machine (Model: 0577-86365889, Wenzhou Zhiguang Shoe-Making Machine Co. Ltd).

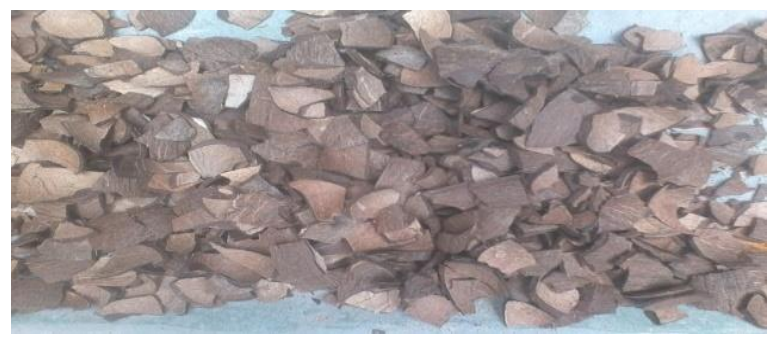

(a)

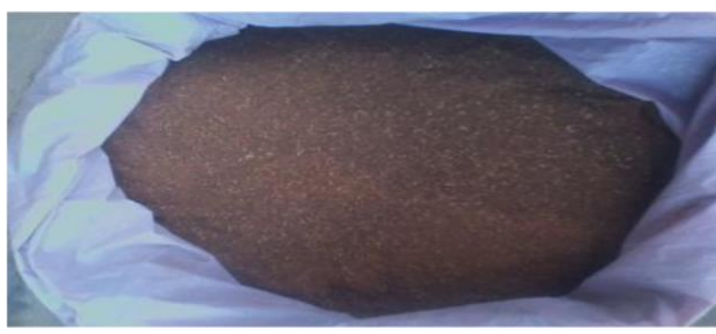

(b)

Figure 1: (a) Crushed coconut shells and (b) sieved coconut shell powder

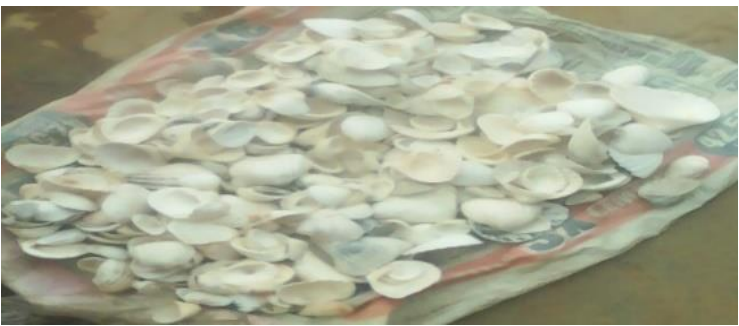

(a)

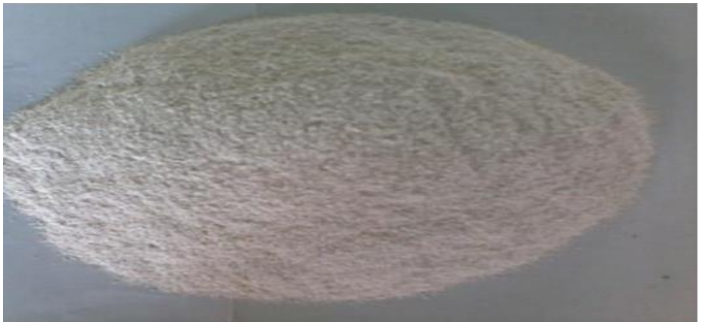

(b)

Figure 2: (a) Seashells and (b) sieved seashells powder

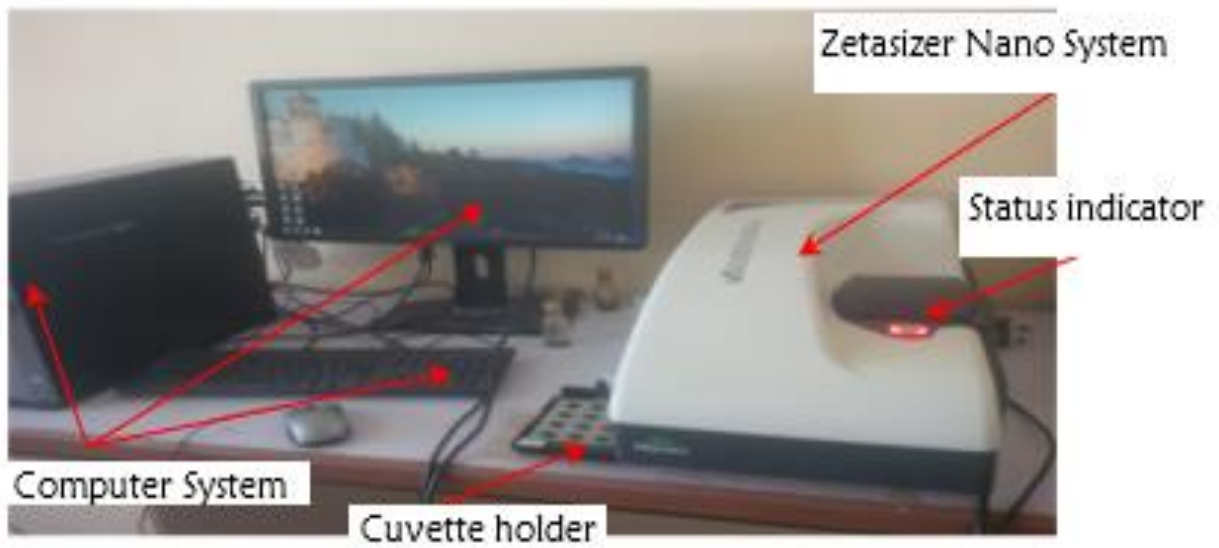

Figure 3: Particle Size Analyser 


\section{Research Methodology}

4.1 Powder Preparation

The method in preparation of the coconut shell and seashell powder involve washing with soap as well as detergent, cleaning using dried cloth, drying in an hot air oven operating at a temperature of $150^{\circ} \mathrm{C}$ followed by crushing using pestle and mortar as well as grinding with grinding machine and finally sieving using a sieve size of $10 \mu \mathrm{m}$.

\subsection{Particle size Analysis}

The Zetasizer system used in this study measured the particle size of the seashell and coconut shell powder. The system used methanol of $0.5476 \mathrm{cP}$ viscosity as dispersant while the temperature and duration of measurement were set at $25^{\circ} \mathrm{C}$ and 60 minutes respectively. The testing procedure include, preparing the test samples in accordance with sample preparation guidelines outline by the manufacturer and there after loosening the lid of the zetasizer and turning it on. This is followed by choosing the measurement type and cells appropriate for the sample and filling the cells with the prepared test sample after the laser stabilises. Thereafter, measurement of standard operating procedure (SOP) was made to ensure that measurements carried out on the samples were done in a consistent manner. Finally, the cell filled with the prepared samples is inserted into the instrument and measurement is carried out at stabilised temperature. The results displayed on the screen is saved and afterward opened as a measurement file. The result obtained were presented in four section, this include the sample details (record number, sample name, dispersant name, the standard operating procedure (SOP) used, measurement date and time as well as the measurement file name), system details (cell type, temperature, run duration and attenuator), results (zeta potential, standard deviation, peak mean and conductivity) and graph.

\subsection{Composite Production}

Production of samples was carried out using standard procedure outlined by Chemiplastica (2010) and Abutu et al. (2018) using a compression moulding machine. As presented in Table 4, the composition of the coconut shell and seashell-reinforced samples as well as process parameters (moulding pressure, moulding temperature, curing time and heat treatment time) remained constant throughout the production process. In order to improve the properties of the composites, samples produced were subjected to further heat treatment using a hot air oven operating at a temperature of $150^{\circ} \mathrm{C}$.

\subsection{Characterization of Composites}

In order to study its performance of the developed composites, samples characterized using standard testing procedures shown in Table 5.

Table 3: Materials used for production of composites

\begin{tabular}{|c|c|c|}
\hline Function & Coconut shell-based composite & Seashell-based composite \\
\hline Reinforcement & Coconut shell powder & Seashell powder \\
\hline Binder & Epoxy resin & Epoxy resin \\
\hline Abrasives & Alumina & Alumina \\
\hline Friction Modifier & Graphite & Graphite \\
\hline
\end{tabular}

Table 4: Percentage composition and process parameters

\begin{tabular}{lc|ll}
\hline \multicolumn{2}{c|}{$\%$ Compositon } & \multicolumn{2}{c}{ Process parameters } \\
\hline Reinforcement & 52 & Moulding pressure (MP) & $14 \mathrm{MPa}$ \\
Binder & 35 & Moulding Temperature (MT) & $160^{\circ} \mathrm{C}$ \\
Abrasives & 8 & Curing time (CT) & $12 \mathrm{~min}$ \\
Friction Modifier & 5 & Heat treatment time (HTT) & $1 \mathrm{hr}$ \\
\hline
\end{tabular}

Table 5: Testing Equipment and methods

\begin{tabular}{lll}
\hline Properties & Equipment used & Testing method/standard \\
\hline Ultimate Tensile Strength (MPa) & Universal testing machine & ASTM D638 type IV mode \\
Bending Strength (MPa) & Universal testing machine & EN ISO 178:2003 \\
Hardness (Shore D Scale) & Durometer & ASTM D2240 type D scale \\
Compressive Strength (MPa) & Universal testing machine & ASTM D695 \\
Impact Strength $(\mathrm{J} / \mathrm{mm})$ & impact tester (Charpy mode) & ASTM E23 \\
Coefficient of Friction & Inclined plance (15) & S.O.N. Act, 2015 \\
Wear Rate (mg/m) & Antopaar Tribometer & ASTM G99 \\
\hline
\end{tabular}




\section{RESULTS AND DISCUSSIONS}

\subsection{Polydispersity Index and Z-Average}

The summary of polydispersity index (PDI) and Z-average diameters in nanometres values for each sample of coconut shell (C) and seashell powder (S) are presented in Table 6. The PDI values presented in Table 5 represent an estimate of the width of distribution while Z-average diameter represents the mean hydrodynamic diameter. These two parameters were automatically calculated on the zetasizer system in accordance to the International Standard on dynamic light scattering, ISO13321 (1996). From the result presented in Table 3, it can be observed that the seashell particles possesses lower distribution width (0.27) compared to the coconut shell powder $(0.342)$ when sieved using similar sieve size $(10 \mu \mathrm{m})$ while the coconut shell (542.3) showed lower Z-average diameter compared to that of seashell powder (1096).

\subsection{Particle Size Distribution}

The results of particle size distribution by volume as well as intensity of the coconut shell and seashell powder are shown in Figure 4-7.

\subsubsection{Coconut Shell Powder}

The intensity distribution of coconut shell particles shown in Figure 4 describes how much light was scattered by the particles in the different size bins while the volume distribution of the particle sizes presented in Figure 5 represent the total volume of particles in the different size bins. As shown in Figure 4, it can be observed that some of the particles appeared to be nano $(\leq 100 \mathrm{~nm})$ and the intensity size distribution from particles in water shows two peak regions of $290 \mathrm{~nm}(0.29 \mu \mathrm{m})$ and $4725 \mathrm{~nm}(4.725 \mu \mathrm{m})$ with standard deviations of $137.8 \mathrm{~nm}(0.1378 \mu \mathrm{m})$ and 803.6 $\mathrm{nm}(0.8036 \mu \mathrm{m})$ by intensity respectively. Similarly, Figure 5 showed that the shape of the distribution seems to be different and appears to be biased towards smaller sizes with fewer of the particles appearing to be nano $(\leq 100 \mathrm{~nm})$. It can also be observed that the volume size distribution of the particles shows two peak regions of $322.4 \mathrm{~nm}(0.3224$ $\mu \mathrm{m})$ and $5041 \mathrm{~nm}(5.041 \mu \mathrm{m})$ with standard deviations of $177.2 \mathrm{~nm}(0.1772 \mu \mathrm{m})$ and $874.7 \mathrm{~nm}(0.8747 \mu \mathrm{m})$ by volume respectively. All the particle sizes of the coconut shell powder were found to be below $10000 \mathrm{~nm}(10 \mu \mathrm{m})$ with little trace of nano particles.

Table 6: Polydispersity Index and Z-average of Samples

\begin{tabular}{ccc}
\hline Sample & PDI & Z-Average Diameter $(\mathrm{nm})$ \\
\hline $\mathrm{C}$ & 0.342 & 542.3 \\
$\mathrm{~S}$ & 0.270 & 1096 \\
\hline
\end{tabular}

\begin{tabular}{|c|c|c|c|c|c|}
\hline & & & Size (d.n... & $\%$ Intensity: & St Dev (d.n... \\
\hline Z-Average (d.nm): & 542.3 & Peak 1: & 290.0 & 74.3 & 137.8 \\
\hline Pdl: & 0.342 & Peak 2: & 4725 & 25.7 & 803.6 \\
\hline Intercept: & 0.131 & Peak 3: & 0.000 & 0.0 & 0.000 \\
\hline
\end{tabular}

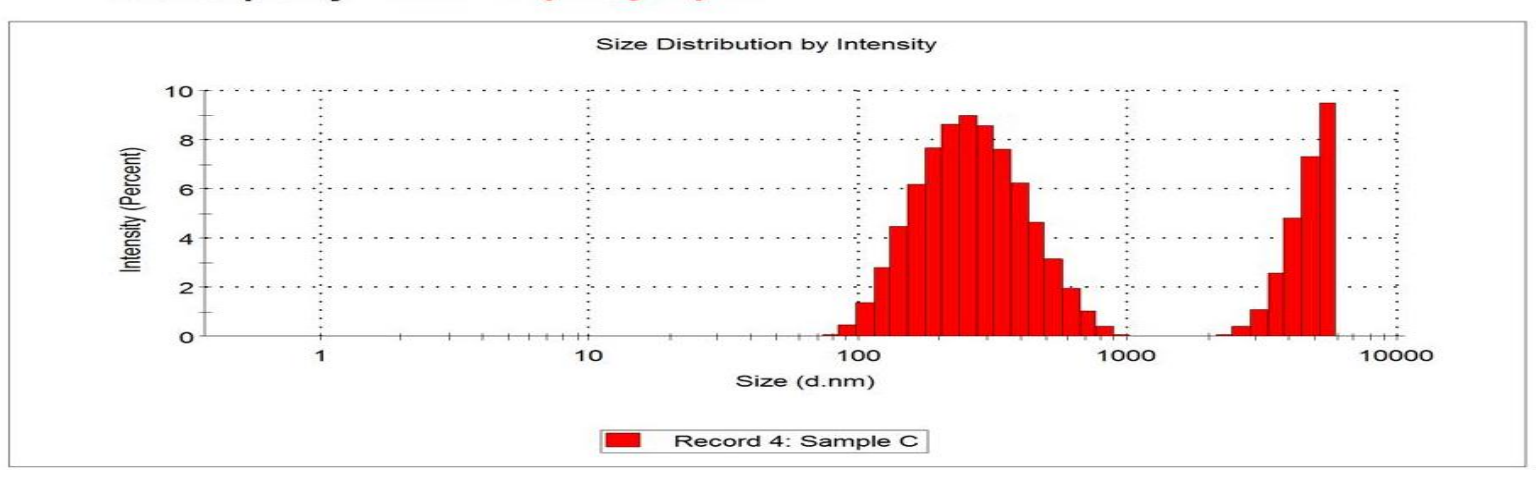

Figure 4: Particle size distribution by percentage intensity 


\subsubsection{Seashell Powder}

The intensity distribution of the seashell particle describes how much light is scattered by the particles at different size bins while the volume distribution of the seashell particle sizes represent the total volume of particles in the different size bins. From Figure 6, it can be observed that the intensity size distribution from seashell particles in water showed a single peak region of $1603 \mathrm{~nm}(0.1603 \mu \mathrm{m})$ with a standard deviation of $1079 \mathrm{~nm}(0.1079 \mu \mathrm{m})$ by intensity. All the particle sizes were found to be below $10000 \mathrm{~nm}(10 \mu \mathrm{m})$ with absence of nanoparticles. Also, in Figure 7, the shape of the distribution seems to be different and appears to favour both smaller and larger sizes. It can also be observed that the volume size distribution of the particles showed a peak region of $1443 \mathrm{~nm}(0.1443 \mu \mathrm{m})$ with a standard deviation of $840.8 \mathrm{~nm}(0.8408 \mu \mathrm{m})$ by volume. Compared to the coconut shell powder, all the particle sizes of the seashell powder were found to be below $10000 \mathrm{~nm}(10 \mu \mathrm{m})$ but with no traces of nanoparticles.

\subsubsection{Characterization of Composite Samples}

The experimental results obtained from the characterization of the coconut shell-based (Figure 8a) and seashell-based (Figure 8b) composite are shown in Table 7. From the experimental results presented in Table 7, it can be observed that the coconut shell-based sample showed better performance (mechanical and tribological properties) with wear rate of $0.0315 \mathrm{mg} / \mathrm{m}$ and friction coefficient of 0.614 compared to the seashell-based composite having wear rate and friction coefficient of $0.0725 \mathrm{mg} / \mathrm{m}$ and 0.525 respectively. This improved performance of coconut shell-based composite may be attributed to lower Z-average (mean hydrodynamic diameter) of coconut shell powder, which was $542.3 \mathrm{~nm}$ versus $1096 \mathrm{~nm}$ obtained for seashell powder. These results are in agreement with the earlier findings.

\begin{tabular}{|c|c|c|c|c|c|}
\hline & & & Size (d.n... & $\%$ Volume: & St Dev (d.n... \\
\hline Z-Average (d.nm): & 542.3 & Peak 1: & 322.4 & 51.6 & 177.2 \\
\hline Pdl: & 0.342 & Peak 2: & 5041 & 48.4 & 874.7 \\
\hline Intercept: & 0.131 & Peak 3: & 0.000 & 0.0 & 0.000 \\
\hline
\end{tabular}

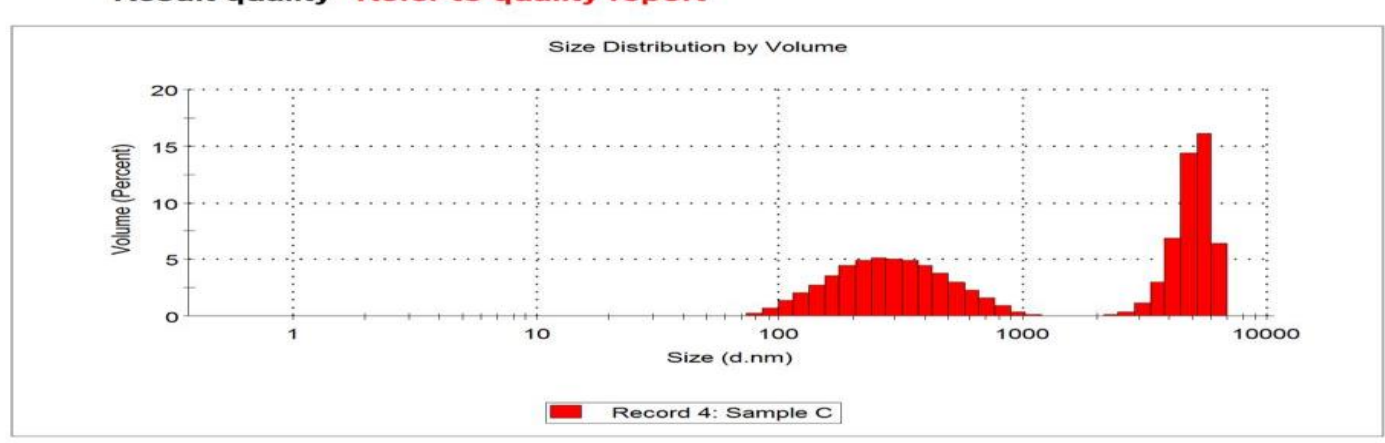

Figure 5: Particle size distribution by percentage volume

\begin{tabular}{|c|c|c|c|c|c|}
\hline Z-Average (d.nm): & 1096 & Peak 1: & $\begin{array}{l}\text { Size (d.n... } \\
1603\end{array}$ & $\begin{array}{l}\% \text { Intensity: } \\
100.0\end{array}$ & $\begin{array}{l}\text { St Dev (d.n... } \\
1079\end{array}$ \\
\hline PdI: & 0.270 & Peak 2: & 0.000 & 0.0 & O.000 \\
\hline $\begin{array}{l}\text { Intercept: } \\
\text { sult quality }\end{array}$ & $\begin{array}{l}0.141 \\
\text { Good }\end{array}$ & Peak 3: & O. 000 & 0.0 & O.0OO \\
\hline
\end{tabular}

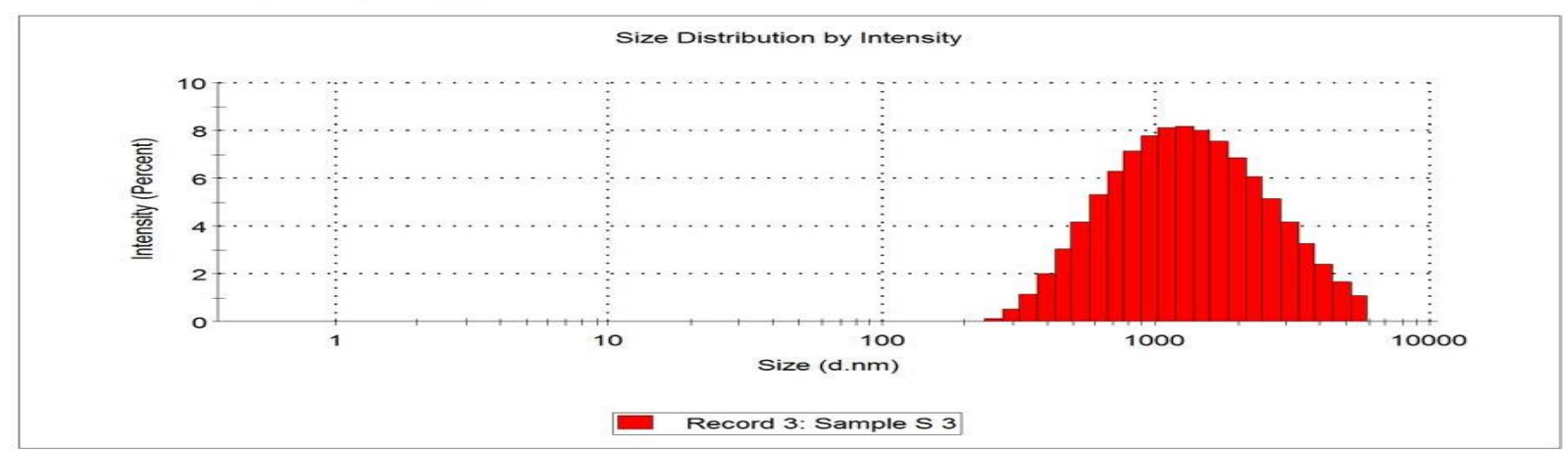

Figure 6: Particle size distribution by percentage intensity 
Yawas et al. (2016) reported that reduced particle size (Z-average) of powder particles in a composite lead to an increased surface area which in turn result in an increase in good interfacial bonding ability between the powder particles and resin. Vignesh et al. (2018) also investigated the effects of particles size distribution on the properties of natural-based composite and revealed that, composites composed of smaller particle sizes give better performance as it is capable of avoiding the occurrence of voids which can pose negative effects on the properties of composites.

\begin{tabular}{|c|c|c|c|c|c|}
\hline & & & Size (d.n... & $\%$ Volume: & St Dev (d.n... \\
\hline Z-Average (d.nm): & 1096 & Peak 1: & 1443 & 100.0 & 840.8 \\
\hline Pdi: & 0.270 & Peak 2: & 0.000 & 0.0 & 0.000 \\
\hline Intercept: & 0.141 & Peak 3: & 0.000 & 0.0 & 0.000 \\
\hline
\end{tabular}

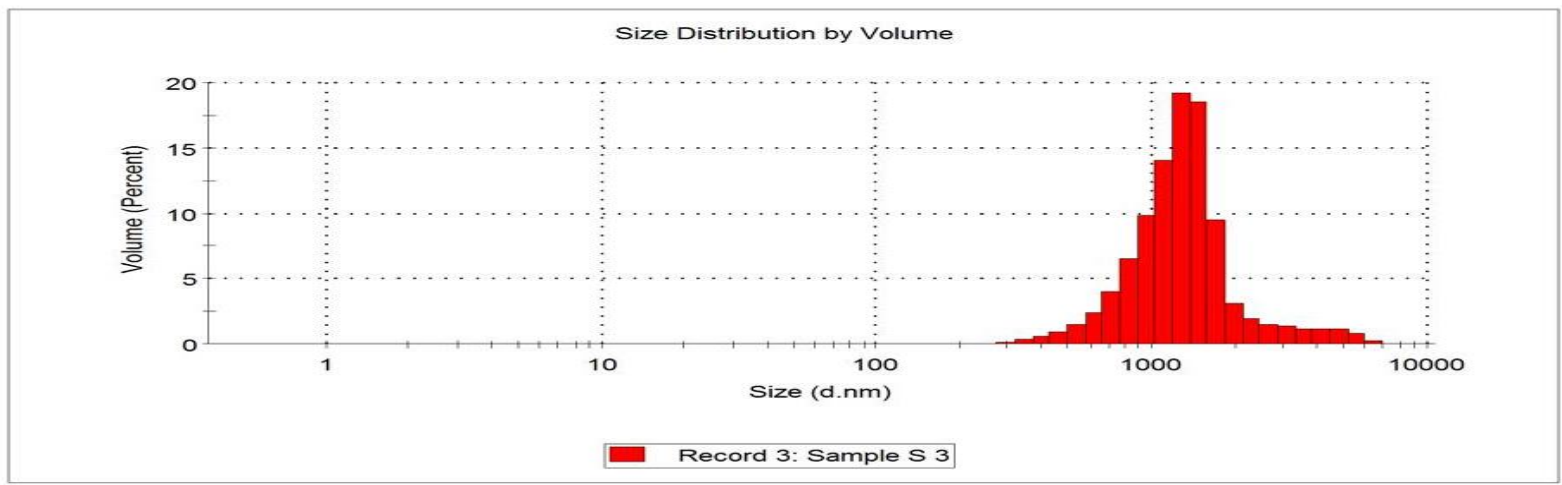

Figure 7: Particle size distribution by percentage volume

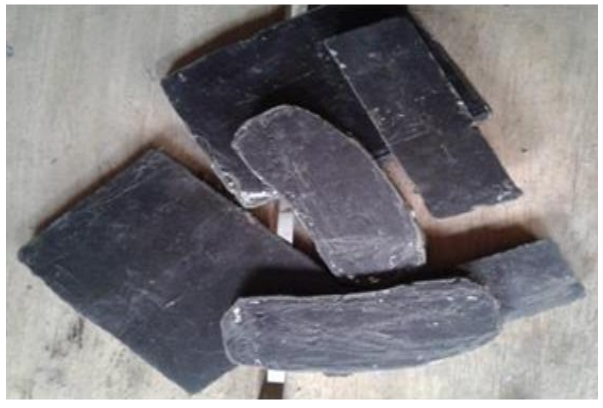

(a)

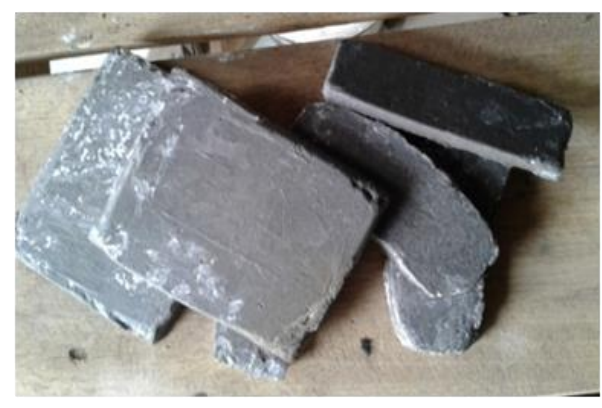

(b)

Figure 8: Heat treated samples (a) Coconut shell-based composite and (b) Seashell-based composite

Table 7: Experimental Results

\begin{tabular}{lcc}
\hline \multicolumn{1}{c}{ Properties } & Coconut shell-based composite & Seashell-based composite \\
\hline Ultimate tensile Strength (MPa) & 7.38 & 2.55 \\
Bending strength (MPa) & 8.34 & 7.25 \\
Hardness (Shore D scale) & 63.31 & 55.81 \\
Compressive strength (MPa) & 3.817 & 2.975 \\
Impact strength (J/mm) & 0.032 & 0.097 \\
Wear rate (mg/m) & 0.0315 & 0.0725 \\
Coefficient of friction & 0.614 & 0.525 \\
\hline
\end{tabular}




\section{CONCLUSIONS AND RECOMMENDATIONS}

This study presents the effects of particles size distribution on the properties of coconut shell and seashell-based composites. Powder samples of the two natural materials were subjected to particle size analysis using an analyzer in order to study their size distribution and thereafter used to separately produce composites of two distinct based materials (coconut shell and seashell powder) with the aim of comparing the effects of the based materials. Based on the experimental results obtained, the following conclusions can be drawn:

1. The coconut shell and seashell powder sieved with the same mesh size $(10 \mu \mathrm{m})$ possesses different Z-average diameter (542.3 and $1096 \mathrm{~nm}$ ) with the coconut shell powder containing some traces of nanoparticles ( $\leq 100$ $\mathrm{nm})$.

2. Also, the volume size distribution of the sieved coconut shell particles shows two peak regions $(322.4 \mathrm{~nm}$ and $5041 \mathrm{~nm}$ ) while the seashell particles showed a single peak region $(1603 \mathrm{~nm})$ with no trace of nanoparticles.

3. Finally, samples produced using coconut shell powder as based material exhibited better mechanical and tribological properties compared to the seashell-based samples. Therefore, compared to seashell, coconut shell powder sieved with $10 \mu \mathrm{m}$ mesh size is the most recommended reinforcement material for use in composite production.

\section{REFERENCES}

Abutu J., Lawal S.A., Ndaliman M.B., Lafia-Araga R.A., Adedipe O. \& Choudhury I. A. (2019). Production and Characterization of Brake pad developed from Coconut shell reinforcement material using Central Composite Design. SN Applied Sciences. 1:18.

Chamoli; K., Jain, D. \& Pathak, K (2008). Ind J Pharm Ed Res, 42 (4), 168-171.

Chemiplastica (2010), Thermoset Processing Manual Compression Molding, Retrieved from, http://www.chemiplastica.com/pdf/compression-molding-guidelines.pdf.

Hermann, S. (2009). Overview of the Methods and Techniques of Measurement of Nanoparticles, nanotrust Possible Health Effects of Manufactured Nanomaterials, Vienna, 24 September 2009. Available at http://www.jrc.ec.europa.eu.

Matthew, L.K. (2012). Thermal Degradation as a Function of Time and Temperature in a Coconut Shell Powder Polypropylene Composite, Master's Thesis, Baylor University, Waco, Texas.

Michele, R.R., Hamestera, P.S.B. \& Daniela, B. (2012). Characterization of Calcium Carbonate Obtained from Oyster and Mussel Shells and Incorporation in Polypropylene. Journal of Materials Research, 15(2), 204-208.

Nia, C. B., Caterina, M., Jordan, T., Molly, M.S. \& Alexander, G.S. (2012), Emerging Techniques for Submicrometer Particle Sizing Applied to Stöber Silica, 28, 10860-10872.

Norazlina, H., Fahmi, A.R.M., \& Hafizuddin, W.M. (2015). $\mathrm{CaCO}_{3}$ from Seashells as a Reinforcing Filler for Natural Rubber, Journal of Mechanical Engineering and Sciences, 8, 1481-1488.

Pei-Jia, L., Wei-En, F., Shou-Chieh, H., Chun-Yen, L., Mei-Lin, H., Yu-Pen, C., Hwei-Fang, C. (2018). Methodology for sample preparation and size measurement of commercial $\mathrm{ZnO}$ nanoparticles, Journal of Food and Drug Analysis, 26, 628-636.

Subhash, P. C. B., Nagaraju, R., Saritha, D., Deepthy, K \& Supraja, B. (2017). Analysis of Particle Size Distribution of Some Powders and Dosage Forms by Skewness and Kurtosis, Journal of Chemical and Pharmaceutical Research, 9(6), 113-119.

Salmah, H., Koay, S.C. \& Hakimah, O. (2013). Surface modification of coconut shell powder filled polylactic acid biocomposites, Journal of Thermoplastic composite material,26 (6), 809-819.

Schaeffer, H. (2014), Seashell, retrieved from www.brittanica.com/EBchecked/topic/5 310 21/seashell.

Tanmaya K.R. (2011). Pyrolysis of coconut shell, M.Tech Thesis submitted to; Department of Chemical Engineering, National Institute of Technology, Rourkela, 31-32.

Vignesh, K., Anbazhagan, K., Ashokkumar, E., Manikandan, R. \& Jayanth, A. (2015). Experimental Analysis of Mechanical Properties of Sea Shell Particles- Polymer Matrix Composite, International Journal of Mechanical and Industrial Technology, 3(1), 13-21.

Will, A., Darby, K., Victoria, A.C., Asa, K.J. \& Matt, T. (2013). A comparative study of submicron particle sizing platforms: Accuracy, precision and resolution analysis of polydisperse particle size distributions, 405, 322-330.

Yawas, D.S., Aku, S.Y. \& Amaren, S.G. (2016). Morphology and properties of periwinkle shell asbestos-free brake pad. Journal of King Saud University- Engineering Sciences, 28,103-109. 